FACTS Field Actions Science Reports

Reports The journal of field actions

Special Issue 21 | 2020

Indoor air quality: tackling the challenges of the invisible

\title{
Who owns the air? Emissions trading and contemporary media art
}

Andrea Polli

\section{OpenEdition}

Journals

Electronic version

URL: http://journals.openedition.org/factsreports/6151

ISSN: 1867-8521

Publisher

Institut Veolia

Printed version

Date of publication: 24 February 2020

Number of pages: 86-89

ISSN: 1867-139X

Electronic reference

Andrea Polli, "Who owns the air? Emissions trading and contemporary media art", Field Actions Science

Reports [Online], Special Issue 21 | 2020, Online since 24 February 2020, connection on 12 January

2021. URL: http://journals.openedition.org/factsreports/6151 


\section{WHO OWNS}

\section{THE AIR? EMISSIONS}

TRADING AND

CONTEMPORARY MEDIA ART

Andrea Polli,

Artist and Professor, University of New Mexico

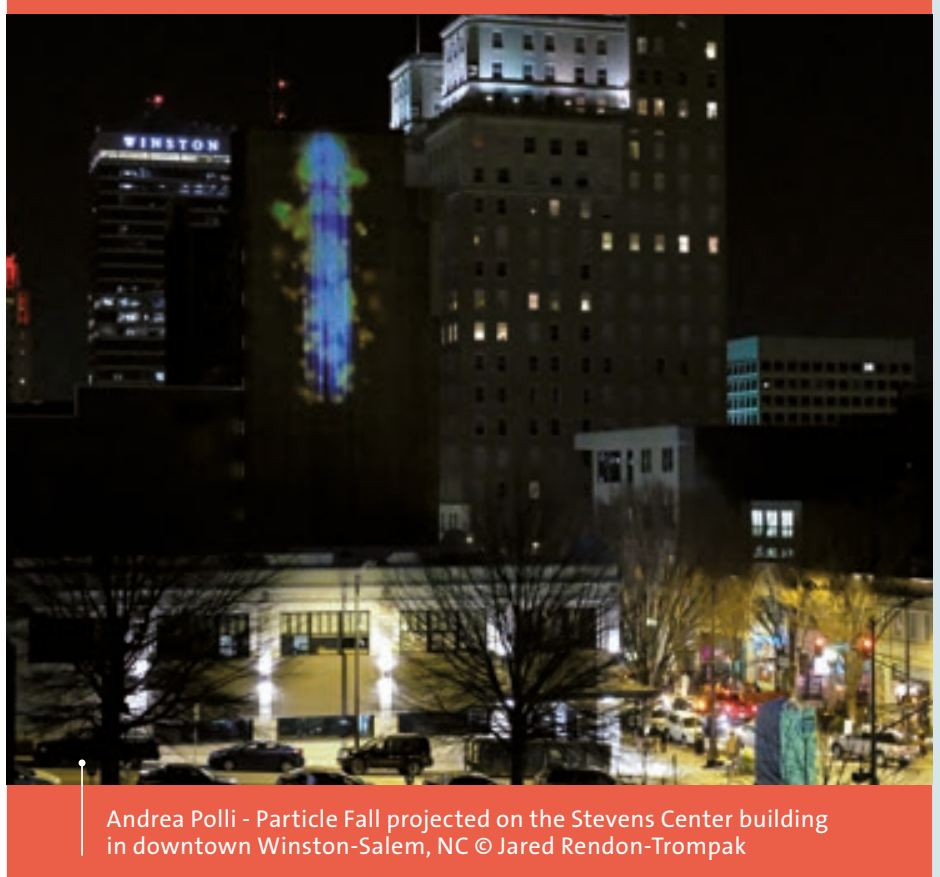

Andrea Polli, professor with appointments in the College of Fine Arts and School of Engineering at the University of New Mexico (UNM), is also an environmental artist working at the intersection of art, science and technology. Her interdisciplinary research has been presented as public artworks, media installations, community projects, performances, broadcasts, mobile and geolocative media and publications. She creates artworks designed to raise awareness of environmental issues. These works often showcase scientific data (obtained thanks to collaborations with scientists and engineers) through sonification, light installation or experimental architecture. She has received numerous grants, residencies (at Eyebeam for instance), and awards including the Fulbright Specialist Program (2011) and the UNESCO Digital Arts Award (2003).
The accelerating climate change crisis and the realization that humans are the primary cause of it has raised questions about ownership and responsibility. Who "owns" the climate change crisis and who is responsible for mitigating and reversing it if possible? One overwhelming response by governments on an international level has been to propose a market solution by selling the atmosphere. Is the commercial marketplace the only answer? How can art, technology and media offer alternative cultural practices and open new forms of understanding the air?

Andrea Polli's projects Airlight series and Particle falls are animated light projections that reveals the invisible dangers in the air we are breathing. It is a dramatic public artwork that raises awareness of the real time presence and impact of particle pollution. 


\section{BUYING THE AIR TO RAISE AWARENESS ON AIR POLLUTION?}

The accelerating climate change crisis and the realization that humans are the primary cause of it has raised questions about ownership and responsibility. Who "owns" the climate change crisis, and who is responsible for mitigating and reversing it if possible? The overwhelming response to these questions by governments internationally has been to propose a market solution, by selling the atmosphere. This article explores the idea of air for sale from economic, political, and cultural arts perspectives, and asks, "Can art help extricate the science and policy of climate change from its current quagmire?".

The idea of environmental and natural resource economics came from the understanding that environmental resources are finite, and since these resources can be destroyed, there should be incentives for protecting them. Ecological economics provides both a mechanism for the valuation of environmental resources and an incentive for keeping within an established environmental "budget". In 1997, the US Congress described it in this way:

"From an economic perspective, pollution problems are caused by a lack of clearly defined and enforced property rights. Smokestack emissions, for example, are deposited into the air because the air is often treated as a common good, available for all to use as they please, even as a disposal site. Not surprisingly, this apparently free good is overused. A primary and appropriate role for government in supporting the market economy is the definition and enforcement of property rights. Defining rights for use of the atmosphere, lakes, and rivers is critical to prevent their overuse. Once legal entitlement has been established, markets can be employed to exchange these rights as a means of improving economic efficiency."

One might think that the idea of "air for sale" is only an abstraction'. There are, however, many ways that air has been commercialized-for example, in the use of bottled oxygen in medicine and sports, or the nearly ubiquitous presence of air conditioning. Recreational uses include the rising popularity of something called the "oxygen bar" and canned air, where oxygen is touted as a cleansing and medical "therapy": customers pay for a five-minute session or so, in which they are able to relax and breathe clean, sometimes scented, air. The oxygen bar started as a trend in the 1990s in Japan, Mexico, and South America and quickly spread to nightclubs, spas, casinos, and malls in Europe and the United States. In 2003, the oxygen bar at Olio!, a restaurant at the MGM Grand Hotel in Las Vegas, boasted 200 to 400 customers per day. Portable canned air is becoming just as popular and widespread. In Japan, a

1 See George England, The Air Trust (1915), discussed in Fleming, Fixing the Sky, 36-38. recent large-scale commercial venture is O2supli, a portable can of oxygen. The oxygen comes in two flavors, "strong mint" (called the brain can) and "grapefruit" (called the body can) at a price of 600 yen (\$7.50) a can: "The idea behind the product is to allow buyers to replenish their oxygen levels any time they feel a lack of it due to stress, fatigue, or other factors.

\section{WHEN ART BECOMES IDEA, IDEA BECOMES COMMODITY²}

Perhaps the arts, specifically contemporary conceptual artworks, have played a role in making buying air culturally acceptable. As creative works, art and architecture have value in society-not just cultural value (although they have that too), but monetary value.

Artists have adopted several strategies to address the politics of air. In the 1950s and 60s, Yves Klein's idea of Air Architecture challenged the definitions of art and architecture, but on a wider scale may have contributed to the commodification of the public resource that is air. Klein was interested in the ways that humans can use science and technology to conquer the ephemeral, to the point of turning even air and fire into building materials. Klein saw science and technology as the saviors of architecture, promoting new forms and structures made from sculpting the air and other "immaterialmaterials." He believed that Air Architecture would actually improve the environment, saying that "Air Architecture must be adapted to the natural conditions and situations, to the mountains, valleys, monsoons, etc., if possible, without requiring the use of great artificial modifications."

Another example is Tue Greenfort's Bonaqua Condensation Cube of 2005, which pays homage to Hans Haacke's Condensation Cube of 1963. The contemporary work uses Bonaqua, a popular brand of bottled water, as the water of condensation. Greenfort is directly addressing the issue of ownership. What was considered a public resource in 1963 had become a commercial product by 2005 . Like the earlier work, the piece is positioned in a gallery with the expectation of being at least attributed a monetary value, and at most purchased. Also like the earlier work, this piece pokes fun at the absurdity of the commercial-gallery system, but paradoxically remains a part of that system.

Laurie Palmer's 2005 Hays Woods/Oxygen Bar project at Carnegie Mellon University highlights the natural processes that create air and draws attention to the fact that air is a public resource: the oxygen bar is a mobile breathing machine, offering free oxygen produced by the photosynthetic work of green plants (from Hays Woods.)

2 Alberro and Buchmann, eds., Art after Conceptual Art

3 Klein, Noever, and Perrin, Air Architecture. 
Pushed around the streets of Pittsburgh, the bar attempted to reproduce in miniature the beneficial cleansing and refreshing effects of green city spaces on the air we breathe. The oxygen bar anticipates the imminent loss of public resources that filter Pittsburgh's dirty air and replenish it with oxygen-in particular, Hays Woods. At the same time, the oxygen bar anticipates the active participation of citizens of Allegheny County in land use decisions affecting public health.

The questions raised by the works discussed here do not represent a criticism of the artworks; the artists should be praised for bringing up these complex questions. The paradoxical problems that arise are a function of the systems in which the works exist, either the gallery art world, with an economy based on the buying and selling of works, or the public art world, in which works are owned by government or private interests, including those works which operate in semi-public forums like the common market or the internet. In the context of climate change, the works bring up larger questions about the potential of art in a time of global environmental crisis, and more specifically the potential of art to collaborate with science.

\section{AIRLIGHT}

Airlight is the name given to a visible white smog caused by the illumination of fine dust particles in the air. The term is often used in Los Angeles, where fumes from car exhaust create airlight, described by author Lawrence Weschler as "a billion tiny suns." The Airlight series first began as Airlight Taipei in summer 2006. Summer in Taipei is unbearably hot and humid, forcing residents to stay in air-conditioned buildings most of the day. The city is crowded, with over six million people in the greater Taipei area. Although public transportation is excellent, several elevated highways cut through the city, like contrails cutting through the dense air. Taipei's geography works against its air quality. Taipei is located at the base of a bowl, surrounded by small mountains with only one small outlet for the stagnant air that often stays trapped for days. In addition, Taipei is downwind of southern China, where the energy demands of recent modernization have meant the development of more coal-burning power plants. Wind flow from west to east brings a large amount of the pollution from China's coal industry to the Taipei air.

During a residency at the Taipei Artist Village, I had the great fortune to meet and collaborate with Dr. Chung-Ming Liu, director of the Global Change Research Center and professor in the Department of Atmospheric Sciences at National Taiwan University. For our project, Dr. Liu gathered and formatted real-time Taipei air quality data for almost twenty sites around the city onto a website. This allowed me to automatically download hourly amounts of particle pollution, ozone, and other pollutants in the atmosphere and translate this information in real-time into a changing rhythmic visual and soundscape, rendering the "noise" of the pollutants into a kind of rhythmic "noise" that expressed what Dr. Liu called the "daily variation" of air quality in the city.
The traffic engineering office of Taipei city possesses many public traffic cameras, so I was able to synchronize the sound of the air quality with live traffic webcam images. I used the pollutant levels to make the images break apart, appearing and disappearing with rising and falling pollutant levels. This repetitive structure created a rhythmic, ambient sound that functioned very much like

background noise.

The imagery was also structured around the idea of noise. The original image was an unaltered traffic cam image that would pixelate based on the levels of pollutants in the air. This has the effect of a blurring and focusing of the image, in a rhythmic way in time with the sound. The rhythmic blurring and focusing of the image produced the impression of quivering or breathing, giving the image a kind of life. In discussing ephemeral and process-based art, Steven Connor says that "in much recent art, air has become the marker, not of the difference between art and life, but of the aspiration of art to trespass beyond its assigned precincts,

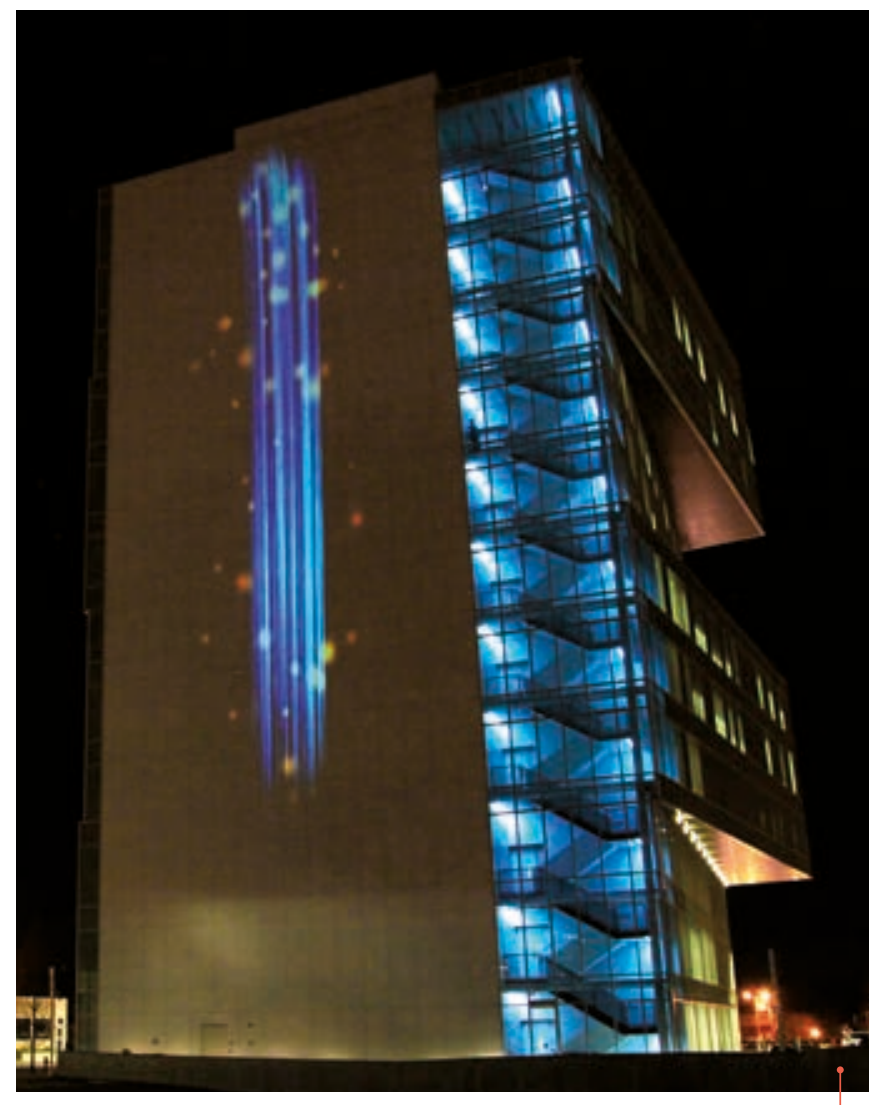

Particle Falls @ Jared Rendon-Trompak 


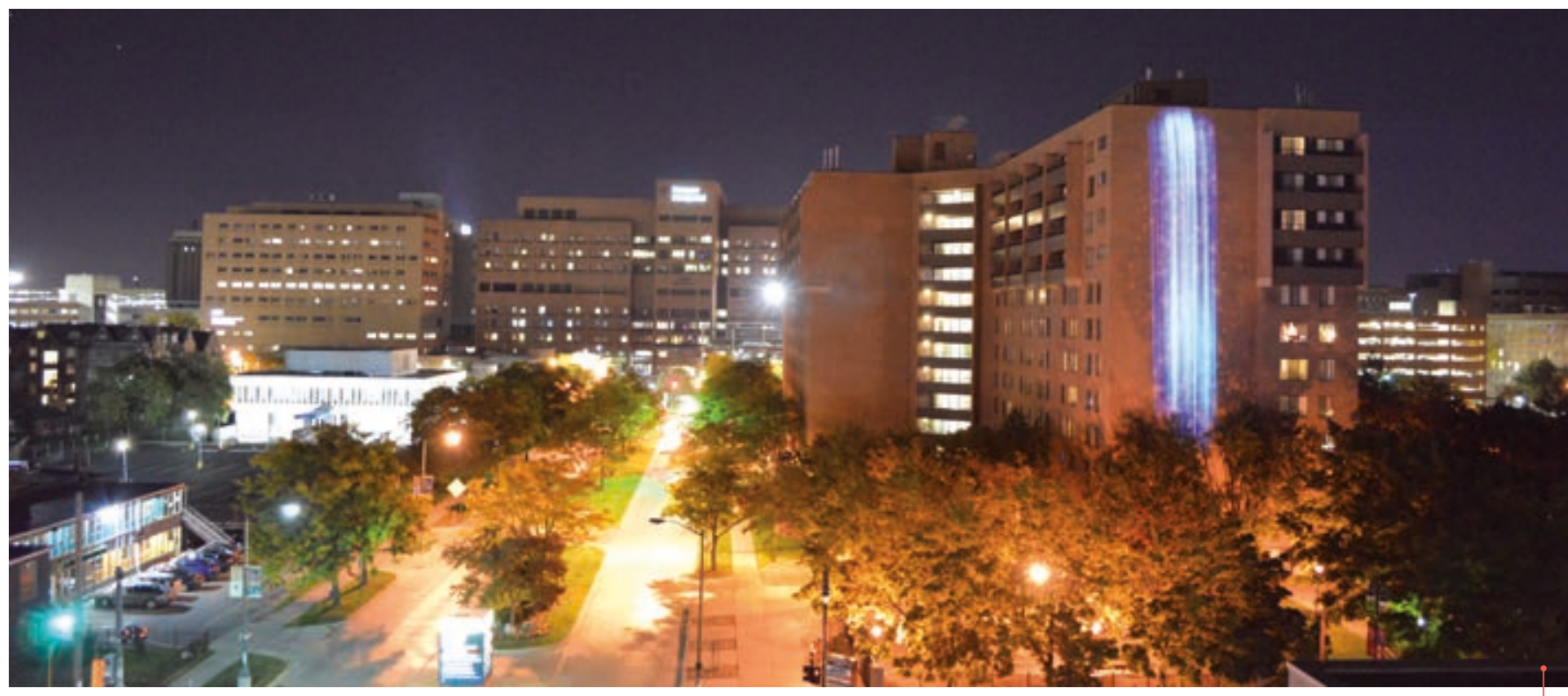

Particle Falls ๔ Jared Rendon-Trompak

to approach and merge into the condition of life." In the Airlight series, I have attempted to give a kind of "life" to the air quality data being collected, creating an alarming scream and image blur that increases in intensity as the levels of pollutants increase.

\section{PARTICLE FALLS}

The creation of Particle Falls fulfills three basic objectives: to use art and technology to make the invisible visible and tangible to the public; to imagine and present new public space possibilities designed to inspire; and to demonstrate that individuals and communities armed with information can help create positive change.

Particle Falls is a night-time projection that allows viewers to see current levels of fine particulates first presented cascading down the facade of the AT\&T building in San Jose (California), using the latest projection technology. The project includes a nephelometer, which measures the smallest air particles (PM2.5). The global monitoring of these particles is one of the most recent developments in aeronomy. Fewer bright particles over the waterfall mean fewer particles in the air. In essence, Particle Falls is a largescale public art installation that acts as a monitor, an alarm and a thing of beauty all at the same time. The work is made possible thanks to Tim Dye's AirNow project, which consolidates all the US based air quality information and shares live air pollution data throughout the US, to raise awareness of air pollution among the public and thereby encourage behavioral change. Raising awareness about environmental pollution in San Jose was a key aim of Particle Falls. Santa Clara County received a failing grade for air quality in the American Lung Association's 2009 State of the Air Report and currently surpasses unhealthy short-term particle pollution thresholds at a yearly average of 11 days, the $24^{\text {th }}$ highest level in the US. The number of people that airborne particulate pollution kills each year has tripled in California.

Consistent with the city's sustainability aims, the work shows how humans impact the environment. The work was positioned in a transport corridor and was sensitive enough to respond to the pollution of a passing truck or even a pedestrian smoking a cigarette. If installed over a longer period of time, the work would be capable of demonstrating how a public works project like a light rail project might improve the quality of life for the people of San Jose. Since San Jose, Particle Falls has been shown in ten cities internationally, including in Paris in conjunction with the COP21 Climate Conference.

\section{CONCLUSION}

By focusing on particles in the air - rather than carbon dioxide, which is invisible - the artist is broadening her interest to environmental pollution generally.

These projects have a multifaceted approach: from a social perspective, they have encouraged public interaction, providing audiences with web and cell phone access to the data, and allowing citizens to collaborate with scientists, designers and engineers. In addition, from a technological and economic perspective, they have enabled the combination of public art with new and emerging technologies and online media, using updated environmental monitoring data to drive real-time animation, and highlighting new, greener technologies by using alternative energy and lower power consumption systems when possible. 